\title{
No Pig Atoll: Island Biogeography and the Extirpation of a Polynesian Domesticate
}

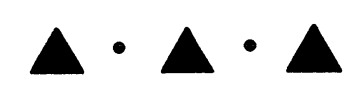

CHRISTINA M. GIOVAS

THE GENERAL ECONOMIC AND SOCIAL SIGNIFICANCE OF THE DOMESTICATED pig (Sus scrofa) is widely recognized in Polynesia (Buck 1938a; Dye and Steadman 1990; Kirch 1984, 2000a; Oliver 1989; Thompson 1971). Not only were pigs a valuable source of protein and industrial raw materials on islands otherwise lacking large terrestrial mammals, but they also functioned in a socioreligious capacity to reify systems of tapu and chiefly hierarchy (Kirch 1991; Pollock 1992). It is therefore not surprising that pigs were widely dispersed across the island South Pacific. Part of what has been variously termed the "portable landscape" or "portmanteau biota" (Crosby 1986; Kirch and Ellison 1994; McNeill 1994), pigs were among the set of plants and animals that prehistoric Polynesians transported with them when they colonized the remote islands of this vast region (Cox and Banack 1991; Kirch 2000a).

Nonetheless, archaeological data in combination with the accounts of early European explorers reveal a pattern of pig distribution far more extensive in prehistory than at the time of historic contact (Fig. 1) (Allen et al. 2001; BayPetersen 1983; Bellwood 1987; Dye and Steadman 1990; Kirch 1991, 2000b; Kirch and Yen 1982; Rolett 1998), suggesting that prehistoric Polynesians either allowed swine herds to die out or intentionally exterminated them. Whichever of these is the case, it appears that pig extirpation in Polynesia constitutes one of the few known instances of domestic species extinction (Ramis and Bover 2001), making it highly significant to the history of human-domesticate interactions.

It has been suggested that animal husbandry was simply less feasible on resource-impoverished islands (Anderson 2001, 2002; Bay-Petersen 1983; Kirch $2000 \mathrm{~b}$ ), particularly since husbandry practices involved feeding pigs cultivated crops, setting up an element of resource competition between pigs and their Polynesian keepers. Underlying this explanation are assumptions about island ecology and its impact on pigs and humans alike. Although the relationship is seldom made explicit, these ecological factors are presumed to operate according to principles of island biogeography, particularly the relationship of island area to species extinction. Other factors may also influence the likelihood of extinction,

Christina M. Giovas is with the Department of Anthropology at the University of Washington, Seattle.

Asian Perspectives, Vol. 45, No. 1 (C) 2006 by the University of Hawai'i Press. 


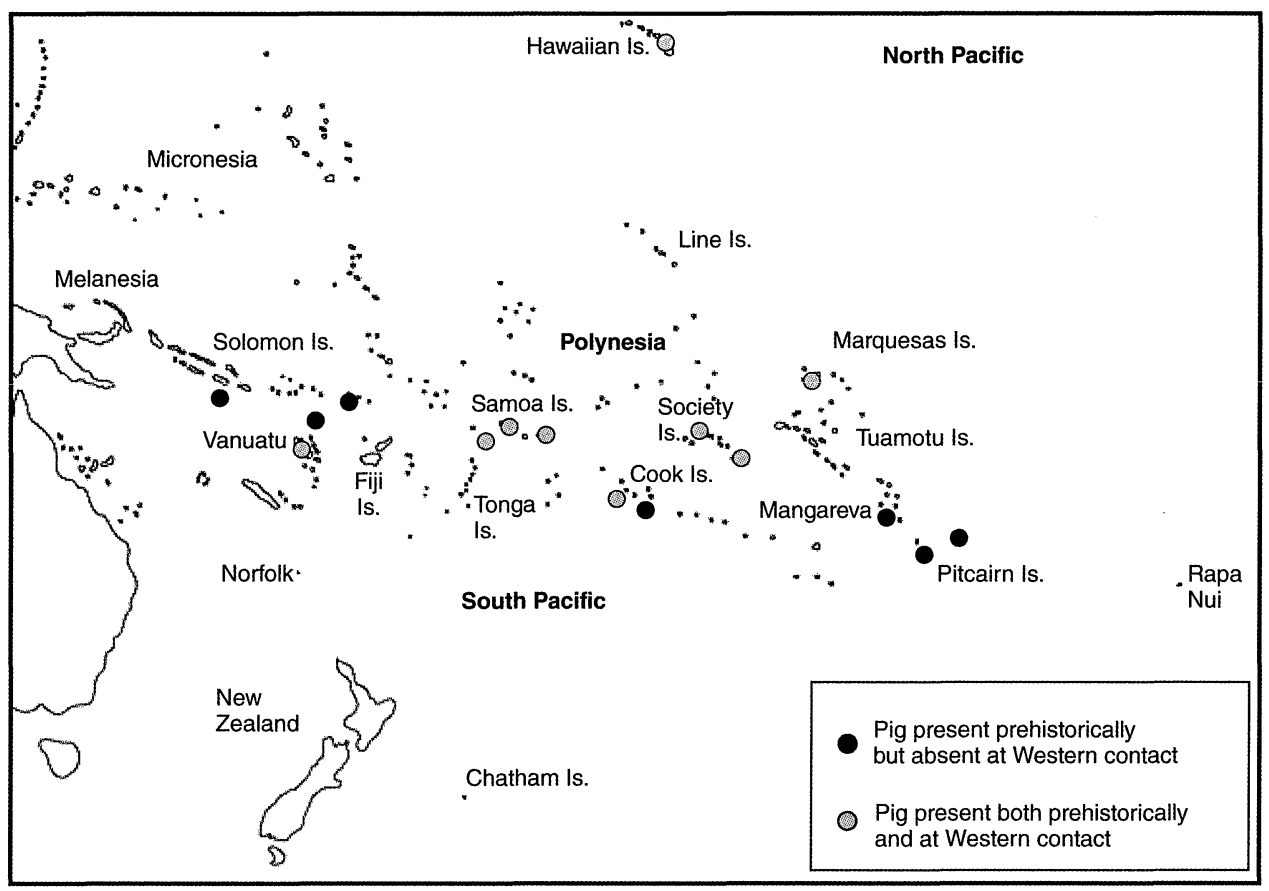

Fig. 1. Geographic pig distribution across Polynesia, showing areas of historic survival and prehistoric extinction. Markers represent multiple cases in some instances.

including island geology, elevation, and latitude and longitude. Here I test the relationship between pig extirpation and these variables. I propose that the pattern of prehistoric distribution for domestic pigs in Polynesia may be best understood in island biogeographic terms and that resource competition may represent the overarching causal mechanism driving pig extirpation, as Kirch (2000b) has argued. To begin, I offer a brief overview of the role of pigs in Polynesian society, followed by a discussion of the relevant principles of island biogeographic theory and the mechanisms - both environmental and cultural-that may have brought about pig extirpation in Polynesia.

\section{THE ECONOMIC AND SOCIAL ROLE OF PIGS}

The significance of the mammalian domesticates pigs and dogs (Canis familiaris) in Polynesia is reflected in the socioeconomic functions they performed. Although their economic importance varied from island to island, in general these mammals were valuable for the protein, fat, and industrial raw material they provided (Anderson 2001). The bones and teeth of domesticates, for example, were used in the manufacture of such items as fishhooks and personal ornaments. Pigs, moreover, figured significantly in Polynesian socioreligious systems of chiefly hierarchy and tapu (Kirch 1991; Pollock 1992), the set of social and religious sanctions through which Polynesians reified social status and granted privileges to 
those of high rank by limiting access to certain prized foods and materials (Dye and Steadman 1990; Hogbin 1971; Pollock 1992). The ritual slaughter of pigs marked religious and ceremonial occasions, and in some instances pigs even served as a stand-in for human sacrifices (Valeri 1985). Ethnohistorical data indicate that the consumption of pig flesh was principally limited to chiefs and highranking people and often restricted along sex lines (Oliver 1974; Williams 1837). Archaeologically, Kirch and O'Day (2003) have used the differential distribution of zooarchaeological remains recovered from elite and commoner residences on Maui, Hawai'i, to demonstrate a link between high status and the consumption of fatty flesh foods, including pork.

Of special note is the role of pig husbandry in prehistoric Polynesian food production systems into which pigs were closely integrated (Kirch 1991). A key aspect of the husbandry system's organization involved pigs' dependence on humans for their fodder. Available ethnohistoric data indicate that pigs were generally fed a vegetarian diet drawn from cultigens and agricultural products that Polynesian peoples grew to meet their own needs. Pig fodder included such items as coconut (Cocos nucifera), breadfruit (Artocarpus altilis), sweet potato (Ipomea batatus), and hala or screwpine (Pandanus sp.), with supplements from household waste, fish, and wild plant contributions (Bay-Petersen 1983; Kirch 1991; Yen 1973:71).

Given the Polynesians' socioeconomic investment in pigs, the disappearance of these animals from many island settings seems to challenge common sense expectations, including the notion that humans will act as a buffer between the environment and their animals. As I will discuss, however, the reliance of pigs on humans for their fodder may have had very real consequences in terms of resource availability, its relationship to island area, and ultimately the course of pig husbandry in Polynesia.

\section{WHY EXTIRPATION?}

The complete absence of pig remains in precontact archaeological sites from such places as New Zealand and Easter Island may reflect the outcome of failed colonization, where viable breeding populations could not be established after landfall possibly due to insufficient herd size or the absence of important cultigens. Failed immigration, where pigs died en route to islands or were never transported to these locations in the first place, might also account for the absence of pigs from certain Polynesian settings (Allen et al. 2001).

Where pigs were successfully introduced, however, their subsequent disappearance from the archaeological record may be ascribed to a variety of possible causes. For instance, historical accidents, including natural disasters such as cyclones and disease, may have played a role in some of these losses. At their most extreme, these events have the potential to bring about the catastrophic loss of a critical proportion of the population. While there is no doubt that such events may occur (Rappaport 1968), they are unlikely to account for all extinctions of Polynesian pigs across the South Pacific.

Human action has been implicated as another culprit in pig extirpation. Both Polynesian oral tradition and ethnohistoric reports suggest that organized extermination of domesticated animals was carried out on a number of islands within 
ethnographic memory, including Anuta in the Solomon Islands and Aitutaki in the Cook Islands (Kirch 2000b; Kirch and Yen 1982; Luomala 1960a; Yen and Gordon 1973). These sources recount how free-roaming mammalian domesticates were hunted down by islanders and exterminated for uprooting crops and gardens (Ellis 1829; Oliver 1974). As Yen and Gordon report for Anuta, "The Anutans themselves recall that in the recent past they imported a few pigs from Tikopia, but quickly killed them off when the unpenned animals began foraging in the Anutan gardens" (92). The intentional eradication of pigs is not necessarily a historically particular explanation. There may be an underlying set of pressures inherent to the island experience in Polynesia that ultimately encourages the extirpation of these animals in many contexts. Kirch (2000b) has suggested that extirpation, including instances of organized extermination, may be the end product of a series of systematic ecological forces shaping human action. These forces would have influenced human socioeconomic strategies in ways that through time ultimately favored or discouraged animal husbandry.

A number of researchers have proposed that the pattern of survivorship for Polynesian domesticated mammals in general reflects the effects of resource limitations (Allen et al. 2001; Anderson 2001; Bay-Petersen 1983; Kirch 2000b). These limitations would have been set first and foremost by such ecological factors as island geology, climate, precipitation, frequency of drought, availability of marine resources, and abundance of freshwater sources. These ecological factors in turn would have regulated human population size and the intensity of agricultural production, both of which would have been crucial determinants of the extent of animal husbandry given the cultigen diet of pigs.

Pigs in the Island Pacific were likely economically expensive animals to maintain. Polynesians may have actually sustained a loss for the return on energy invested in the care and husbandry of pigs. Such a loss would result from the cost in human labor invested to grow crops for pigs and from the inefficiencies in energy transfer between trophic levels. Prehistoric Polynesians could have extracted more calories through the direct consumption of cultigens than through feeding these first to pigs and then consuming their pork. In the latter situation, a greater part of the energy transfer is lost to the metabolic processes of the pig. ${ }^{1}$

In times of resource shortfall, pigs would have been effectively competing with people for the same agricultural produce, placing Polynesians in a position in which the benefits of pig husbandry may have been outweighed by its relatively high economic (energetic) cost. As Kirch and others have suggested (Allen et al. 2001; Bay-Petersen 1983; Kirch 2000b), trophic competition on this level may explain why animal husbandry failed in many parts of Polynesia. Those islands prone to resource shortfalls would have been at a greater risk for failure of pig husbandry simply because crop harvests may have been insufficient to support both humans and pigs. The onset of this effect need not have been sudden or severe. Instead, it may have operated slowly but systematically over decades or more. $^{2}$

Unlike explanations that rely on historically particular events, trophic competition represents a general ecological mechanism operating in a systematic fashion across Oceania. The intensity of trophic competition and the severity of its impact on domestic pigs would have varied from island to island depending on the vari- 
ables involved. Kirch (2000b) suggests that it should be expected on islands experiencing resource limitations, high human population density (at least initially), resource competition, social conflict, and warfare. Indeed, population density, competition, and conflict are often functions of resource limitations operating in conjunction with availability of territory-especially arable land (Kirch 1984; Ladefoged 1995). Island size may therefore represent one of the critical components determining the likelihood of trophic competition and, following this, the likelihood of extirpation of pigs in Polynesia.

Since a provocative association between island size and extirpation is suggested by the available data on the archaeological and ethnographic distribution of pigs, a number of researchers have considered island area to bear critically on the issue of pig extinction. Bay-Petersen (1983) contends that extirpation of domesticated mammals occurred principally on smaller islands, particularly those under $50 \mathrm{~km}^{2}$. This argument, however, is based solely on a qualitative appraisal of the known cases for pig and dog extinction in Polynesia. Bay-Petersen suggests that the main limiting factors to animal husbandry would have been the extent to which the maintenance of domesticates competed with the production of other food resources, the degree to which domesticate-based protein could be replaced by other foods, and the ability of domesticates to live within or coexist with a largely man-made habitat. The significance of these factors, as with those that Kirch considers crucial to extirpation likelihood, can be associated with ecological constraints, including island area. Although the notion that island size is a factor in Polynesian pig extinction has existed for decades, it has never been quantitatively assessed.

This article builds on the efforts of these researchers and provides that assessment. However, it must be noted that if trophic competition represents the driving mechanism behind pig extirpation in Polynesia, then the critical variable regulating potential conflict between pig husbandry and human needs is not necessarily island area-it is island productivity. While island size can influence resource productivity, other factors may be equally important. Climate, soil properties, and geological substrate influence the resource and agricultural productivity of islands. High volcanic islands, for example, typically have high rainfall, more fertile soils, and greater resource diversity, the latter of which is tied in part to the creation of new habitats through elevation gains. In contrast, low coral atollswhich generally have shallow, nutrient-poor soils that do not retain water wellare less productive, and their ability to support agriculture is relatively reduced. Thus, for an island of a given size, productivity can vary drastically based on a number of critical variables unrelated to area. Ecological factors that may serve as a proxy for island productivity in addition to island size, therefore, include island geology, maximum elevation above sea level, and latitude (an estimate for climate).

Although seldom stated overtly, discussions on the role of environmental constraints in pig extinction draw implicitly on the principles of island biogeography. For this reason, I now turn to an overview of these principles and evaluate the hypothesized relationship between ecology and extinction within the framework of island biogeographic theory. By doing so, I hope to make explicit the assumptions and factors that bear directly on the issue of Polynesian pig extinction. 


\section{ISLAND BIOGEOGRAPHY}

Much investigation has augmented our understanding of island biogeography since MacArthur and Wilson $(1963,1967)$ first introduced the equilibrium theory of biogeography. It is the basic principles of this body of theory, however, that remain the most informative to the island extinction issue under consideration. Of these, the species-area relationship is the most pertinent as it relates to extinction subsequent to successful colonization, but prehistoric pig distribution cannot be discussed without also considering the effects of insular isolation described by the species-isolation relationship.

\section{Island Area}

The species-area relationship describes one of the most well-established phenomena in biogeography. All else being equal, the number of species (species richness) tends to increase with increasing area. Smaller islands have fewer species per unit of area than larger islands, and these in turn have fewer species per unit of area than continents (Rosenzweig 2004). As a corollary to this, smaller islands are able to support fewer individuals of a given species because of habitat and resource requirements. While on a continent a population may endure at low levels through the exchange of individuals between local areas, this is less feasible for small islands (Brown and Lomolino 1998). In general then, the smaller the island the more vulnerable its biota are to extinction (Steadman 1995).

Not all successful immigrants to an island will be successful colonizers. Some will persist for a time, only to die out. Successful colonization (rate of extinction) is a function of such critical factors as habitat composition, predation, and competitive interactions with other organisms (MacArthur and Wilson 1967). These factors themselves, however, are shaped by habitat diversity, which tends to be greater for islands of larger size. Thus island area may serve as a proxy for these variables. Although only very general, relationships between species richness, extinction likelihood, and island area are strong enough that they may be used to examine the pattern of pig extirpation in Polynesia. If the general biogeographic rules of insular area apply, pig extirpation should occur more frequently on smaller islands. If they do not, we might expect pig extirpation to correlate with some other variable whose influence overrides that of area.

\section{Isolation}

The second critical component to understanding the biogeographic distribution of pigs in Polynesia is island isolation. The effect of isolation on the likelihood of species colonizing an island is captured in the species-isolation relationship. Simply stated, because of the fact that isolated islands are farther from a source of potential immigrants, there is a diminished likelihood that species will successfully reach more remote islands. Species richness thus tends to decline with distance on islands farther from significant archipelagoes or continents (Brown and Lomolino 1998; MacArthur and Wilson 1967). Relative isolation may explain why pigs are archaeologically unknown on Easter Island, Norfolk Island, the Chatham Islands, and New Zealand, especially since recently introduced feral pigs do quite well on some of these islands today (Clarke and Dzieciolowski 1991a, 1991b). 
Long, difficult oceanic voyages may have thwarted the successful introduction of viable pig populations, particularly if contact was limited and therefore the opportunities for introduction were few.

On the other hand, where human interaction between islands was frequent, it may have supplied a type of rescue effect (Brown and Kodric-Brown 1977) in which the continual immigration of domesticates safeguarded against their disappearance from an island. In this scenario, isolation comprises not only a geographic but also a social component in which substantial geographic isolation may be overcome in part by cultural forces. Weisler (1994, 1995, 1996, 1997; Woodhead and Weisler 1997), for example, has documented the existence of a longdistance economic interaction sphere among the remote islands of Mangareva and the Pitcairn group. The subsequent decline of settlements on Pitcairn and Henderson may have come about in part because of the breakdown of interisland voyaging between these islands.

It is quite likely, therefore, that isolation played a role in shaping the distribution of Polynesian pigs on islands across the Pacific, and one could speculate that isolation may be correlated with archaeological pig distribution. However, the commensal nature of pigs and their dependence on Polynesians for dispersal confounds an easy and accurate measure of island isolation. Polynesian pigs were domestic mammals whose initial distribution in the Pacific is wholly the result of cultural processes. Unlike strict biological studies, "isolation" in the case of prehistoric Polynesia cannot be captured by a measurement of linear distance to the nearest island or continent; colonization routes and subsequent interisland contact must also be considered. ${ }^{3}$ Unfortunately, the creation of an isolation model is presently limited by what we do not know about Polynesian migration and voyaging. For example, even the genetic relationships of Pacific pigs-and by proxy their pattern of dispersal across Oceania-is understood in only the most general of ways (Allen et al. 2001; Groves 1983; Matisoo-Smith 2001).

Because such a comprehensive model cannot be constructed, I take a different approach here. I test the relationship between the several variables of island size, geology, elevation, and latitude and the likelihood of pig extirpation for the Island South Pacific. As an exploratory measure, I also test the relationship between extinction and island longitude. In theory, this provides a simple test of the isolation model, measuring the distance of pig populations from a dispersal point in the west. In practice, however, as I have argued above, this model is probably too crude to properly capture the cultural forces of Polynesian voyaging and island interaction that facilitated pig introductions and reintroductions.

\section{DATA AND METHODS}

To conduct this analysis, I compiled a sample of 46 Polynesian islands with a known record of pig history (Table 1). Data were recorded on the following: (1) island area $\left(\mathrm{km}^{2}\right) ;(2)$ island geologic type (volcanic, atoll, raised atoll, volcanic and coral mix); (3) maximum elevation in meters above sea level (mASL); (4) latitude in degrees from the equator; (5) longitude (degrees east); (6) the presence/ absence of the pig prehistorically; and (7) and the presence/absence of the pig at the point of Western contact. These data are based on archaeological and ethnographic records and United Nations sources (see Table 1 for references). Although 
Table i. Known Record for Prehistoric and Contact Period Presence and Absence of Pig

\begin{tabular}{|c|c|c|c|c|c|c|}
\hline ISLAND GROUP & ISLAND & $\begin{array}{c}\text { ISLAND } \\
\text { AREA } \\
\left(\mathrm{KM}^{2}\right)\end{array}$ & $\begin{array}{l}\text { PREHISTORIC } \\
\text { PIG }\end{array}$ & $\begin{array}{l}\text { HISTORIC } \\
\text { PIG }\end{array}$ & $\begin{array}{l}\text { FAUNAL } \\
\text { SCENARIO }\end{array}$ & SOURCE \\
\hline \multirow[t]{2}{*}{ Chatham } & Chatham & 744.6 & 0 & 0 & $\mathrm{~N} / \mathrm{P}$ & Bellwood 1987; Sutton 1982 \\
\hline & Pitt & 65.9 & 0 & 0 & $\mathrm{~N} / \mathrm{P}$ & Bellwood 1987; Sutton 1982 \\
\hline \multirow[t]{3}{*}{ Cook } & Aitutaki & 16.5 & $\mathrm{X}$ & $?$ & Uncertain & $\begin{array}{l}\text { Allen 1992; Bay-Petersen 1983; Bellwood 1978; } \\
\text { Bligh } 1969\end{array}$ \\
\hline & Mangaia & 34.5 & $\mathrm{X}$ & 0 & $\mathrm{E}$ & Kirch $2000 b$ \\
\hline & Rarotonga & 67.6 & $\mathrm{X}$ & $\mathrm{X}$ & $\mathrm{S}$ & Bellwood 1978; Williams 1837 \\
\hline Easter & Easter & 173.0 & 0 & 0 & $\mathrm{~N} / \mathrm{P}$ & McCoy 1979 \\
\hline Eastern Caroline & Kapingamarangi & 1.1 & 0 & 0 & $\mathrm{~N} / \mathrm{P}$ & Emory 1986; Leach and Ward 1981 \\
\hline \multirow[t]{4}{*}{ Gambier-Mangareva } & Akamaru & 1.8 & $\mathrm{X}$ & 0 & $\mathrm{E}$ & Beechey 1968; Buck 1938b; Green and Weisler 2004 \\
\hline & Aukena & 1.3 & $\mathrm{X}$ & 0 & $\mathrm{E}$ & Beechey 1968; Buck 1938b; Green and Weisler 2004 \\
\hline & Mangareva & 13.0 & $\mathrm{X}$ & 0 & $\mathrm{E}$ & $\begin{array}{l}\text { Allen et al. 2001; Beechey 1968; Buck 1938b; Kirch } \\
\text { 2000b }\end{array}$ \\
\hline & Taravai & 5.7 & $\mathrm{X}$ & 0 & $\mathrm{E}$ & Beechey 1968; Buck 1938b; Green and Weisler 2004 \\
\hline \multirow[t]{8}{*}{ Hawai'i } & Hawai'i & $10,434.0$ & $\mathrm{X}$ & $\mathrm{X}$ & $\mathrm{S}$ & $\begin{array}{l}\text { Cordy et al. 1993; Gunness 1993; Kirch 1985; } \\
\text { Rosendahl } 1994\end{array}$ \\
\hline & Kaho'olawe & 113.3 & $\mathrm{X}$ & $\mathrm{X}$ & $\mathrm{S}$ & Kirch 1979; Kirch 1985; Ziegler 2002 \\
\hline & Kaua'i & 1434.6 & $\mathrm{X}$ & $\mathrm{X}$ & $\mathrm{S}$ & Bryan 1915; Kirch 1985; Ziegler 2002 \\
\hline & Lāna'i & 358.4 & $\mathrm{X}$ & $\mathrm{X}$ & $\mathrm{S}$ & Bryan 1915; Kirch 1985; Ziegler 2002 \\
\hline & Maui & 1903.3 & $\mathrm{X}$ & $\mathrm{X}$ & $\mathrm{S}$ & Bryan 1915; Kirch 1985; Ziegler 2002 \\
\hline & Moloka'i & 677.9 & $\mathrm{X}$ & $\mathrm{X}$ & $\mathrm{S}$ & Bryan 1915; Kirch 1985; Ziegler 2002 \\
\hline & Ni'ihau & 182.8 & $\mathrm{X}$ & $\mathrm{X}$ & $\mathrm{S}$ & Bryan 1915; Kirch 1985; Ziegler 2002 \\
\hline & O’ahu & 1583.3 & $\mathrm{X}$ & $\mathrm{X}$ & $\mathrm{S}$ & Kelly and Clark 1980; Kirch 1985; Tuggle 1997 \\
\hline \multirow[t]{3}{*}{ Marquesas } & Nuku Hiva & 345.0 & $\mathrm{X}$ & $\mathrm{X}$ & $\mathrm{S}$ & Rolett 1998; Sinoto 1979; Suggs 1961 \\
\hline & Tahuata & 70.8 & $\mathrm{X}$ & $\mathrm{X}$ & $\mathrm{S}$ & Rolett 1998; Sinoto 1979 \\
\hline & Ua Huka & 82.4 & $\mathrm{X}$ & $\mathrm{X}$ & $\mathrm{S}$ & Conte 2002; Sinoto 1979 \\
\hline \multirow[t]{3}{*}{ New Zealand } & North & $115,182.8$ & 0 & 0 & $\mathrm{~N} / \mathrm{P}$ & Allen et al. 2001; Bellwood 1987; Davidson 1984 \\
\hline & South & $145,836.4$ & 0 & 0 & $\mathrm{~N} / \mathrm{P}$ & Allen et al. 2001; Bellwood 1987; Davidson 1984 \\
\hline & Stewart & 1814.7 & 0 & 0 & $\mathrm{~N} / \mathrm{P}$ & Allen et al. 2001; Bellwood 1987; Davidson 1984 \\
\hline Niue & Niue & 263.7 & 0 & 0 & $\mathrm{~N} / \mathrm{P}$ & $\begin{array}{l}\text { Bay-Pertersen 1987; Walter 1998; Walter and } \\
\text { Anderson } 2002\end{array}$ \\
\hline
\end{tabular}




\begin{tabular}{|c|c|c|c|c|c|c|}
\hline Norfolk & Norfolk & 36.8 & 0 & 0 & $\mathrm{~N} / \mathrm{P}$ & Specht 1984 \\
\hline \multirow[t]{2}{*}{ Pitcairn } & Henderson & 37.3 & $\mathrm{X}$ & 0 & E & Weisler 1995 \\
\hline & Pitcairn & 4.2 & $\mathrm{X}$ & 0 & $\mathrm{E}$ & Anderson 2001 \\
\hline \multirow[t]{3}{*}{ American Samoa } & Ofu & 7.5 & $\mathrm{X}$ & $\mathrm{X}$ & $\mathrm{S}$ & Hunt and Kirch 1987; Nagaoka 1993 \\
\hline & Olosega & 5.4 & $\mathrm{X}$ & $\mathrm{X}$ & $\mathrm{S}$ & Hunt and Kirch 1987; Kirch and Hunt 1993 \\
\hline & $\mathrm{Ta}^{a} \mathrm{u}$ & 45.7 & $\mathrm{X}$ & $\mathrm{X}$ & $\mathrm{S}$ & Hunt and Kirch 1987; Kirch and Hunt 1993 \\
\hline \multirow[t]{3}{*}{ Western Samoa } & Manono & 2.9 & $\mathrm{X}$ & $\mathrm{X}$ & $\mathrm{S}$ & Janetski 1980 \\
\hline & Savai'i & 1717.6 & $\mathrm{X}$ & $\mathrm{X}$ & $\mathrm{S}$ & Anderson 2001 \\
\hline & 'Upolu & 1125.1 & $\mathrm{X}$ & $\mathrm{X}$ & $\mathrm{S}$ & Davidson 1969; McLinlay 1974 \\
\hline \multirow[t]{4}{*}{ Society } & Huahine & 82.1 & $\mathrm{X}$ & $\mathrm{X}$ & $\mathrm{S}$ & Emory 1979; Forster 1777 \\
\hline & Mo'orea & 132.0 & $\mathrm{X}$ & $\mathrm{X}$ & $\mathrm{S}$ & Rappaport and Rappaport 1967 \\
\hline & Tahiti & 1068.8 & $\mathrm{X}$ & $\mathrm{X}$ & $\mathrm{S}$ & Forster 1777; Henry 1928; Oliver 1974 \\
\hline & Teti'aroa & 12.8 & $\mathrm{X}$ & $\mathrm{X}$ & $\mathrm{S}$ & Sinoto and McCoy 1974 \\
\hline \multirow[t]{3}{*}{ Solomon } & Anuta & 2.6 & $\mathrm{X}$ & 0 & $\mathrm{E}$ & Yen and Gordon 1973 \\
\hline & Bellona & 11.0 & $\mathrm{X}$ & 0 & E & Bay-Petersen 1983; Cram 1975 \\
\hline & Tikopia & 5.0 & $\mathrm{X}$ & 0 & $\mathrm{E}$ & Firth 1959; Kirch 2000b; Kirch and Yen 1982 \\
\hline \multirow[t]{2}{*}{ Tuamotu } & Anaa & 37.7 & 0 & 0 & $\mathrm{~N} / \mathrm{P}$ & Emory 1975 \\
\hline & Takaroa & 192.0 & 0 & 0 & $\mathrm{~N} / \mathrm{P}$ & Emory 1975 \\
\hline Tonga & Niuatoputapu & 15.6 & $\mathrm{X}$ & $\mathrm{X}$ & $\mathrm{S}$ & Kirch 1988; Kirch and Hunt 1988 \\
\hline Vanuatu & Malo & 180.0 & $\mathrm{X}$ & $\mathrm{X}$ & S. & Green 1979 \\
\hline
\end{tabular}

Presence is indicated by $\mathrm{X}$, absence is indicated by 0 . Faunal scenario is the summed history for each island. $\mathrm{E}=$ prehistoric introduction followed by extirpation. $\mathrm{S}=$ indefinite survival of pigs after introduction. $\mathrm{N} / \mathrm{P}=$ pigs never present. Island land area is based on data from the United Nations Environment Programme Island Directory. 
certain islands may exhibit evidence for prehistoric pig, without the critical demonstration of their presence or absence at the point of European contact such islands are unsuitable for testing and have been omitted from the analysis. For this reason also, many islands that have experienced archaeological investigation, such as Tongatapu (Tonga), Raiatea (Societies), and some of the Cook Islands, are not included in this analysis; contact period records describing the status of pigs on these islands could not be identified.

The basic criterion used to establish the existence of prehistoric pig on an island is the presence of definitive suid zooarchaeological remains. This standard is applied irrespective of sample size. On islands where pig remains are quite rare, it is possible that these do not, in fact, represent the successful introduction of pigs but rather the occasional importation of a haunch of meat or skeletal parts for industrial raw material from elsewhere. On Henderson Island, for example, Weisler (1995) believes that the several fragments of pig bone recovered from only 2 of 16 excavated sites are unlikely to be the product of pig husbandry. He suggests instead that these few bones may have been introduced as butchered food from a neighboring island. Given that pig introductions on Henderson in the historic period failed (Scott 1993), Weisler's arguments are reasonable. It is equally plausible, however, that scarcity of pig remains represents a small or short-lived pig population. In the absence of additional data, I use a simplified model that scores the presence of any identifiable pig remains as indicative of an established prehistoric population on that island.

The contact period status for pigs was determined through ethnographic and historical accounts in which the presence or absence of pigs is reliably and specifically noted for a given island. ${ }^{4}$ Western contact, of course, is an arbitrary point for measuring the survival of pigs in Polynesia, not only because it is variable across the Pacific but also because-depending on the timing of introduction-different islands will have pig histories of varying lengths. It is possible that in some settings pigs may have eventually gone extinct but that the arrival of Europeans truncated this process, yielding a positive record for pig survival where extirpation may otherwise have been recorded given sufficient additional time. Despite this arbitrary element, initial Western contact is used as a benchmark because subsequent historic-period activities brought about the (re-)introduction and spread of European and Polynesian pigs throughout the Pacific (Allen et al. 2001; Clarke and Dzieciolowski 1991a; Emory 1975; Scott 1993), in essence blurring a centuriesold record of prehistoric processes.

Classification of islands along these lines yields three possible scenarios for pig husbandry in the Pacific:

1. Introduction of pigs followed by the maintenance of viable populations through time

2. Introduction of pig followed by later extirpation

3. Pigs never introduced

Of the total of 46 cases, pigs survived on 24 islands, died out on 10 , and were apparently never introduced to the remaining 11 (see Table 1). One case, Aitutaki, remains equivocal and was therefore excluded from analysis. ${ }^{5}$

The 34 cases where pigs survive or die out comprise the sample for testing here (Fig. 1). The geologic type, elevation, latitude, longitude, and area for this set of islands are provided in Table 2 . In some instances the islands that make up these 
cases consist of archipelagoes exhibiting a shared cultural affinity, as with the Hawaiian Islands. Despite this cultural unity and its obvious implications for island interaction, instances of pig survivorship or extirpation were recorded on an island rather than on an archipelago basis. Thus for the Hawaiian archipelago, consisting of eight main islands, there are eight cases where pigs survive through time rather than one sole case representative of the entire island group. This approach is taken for several reasons. First, islands within an archipelago do not necessarily share the same topography, geology, and climate. Further, archipelago area is problematic to assess. Unlike islands whose borders are definitive, the delineation of archipelagoes - which islands to include or exclude from a cluster - is arbitrary and often no more than a political or cultural convenience. An archipelago is a constructed unit based on implicit notions about how "close" islands are to each other. Further, the open water distance between the islands of an archipelago introduces the element of relative isolation and the question of how to appropriately quantify uninhabited territory, thus confounding a pure measure of the species-area relationship. Moreover, it is inappropriate to generalize from the archipelago level to the island level. We cannot necessarily assume that the history of a particular island within an archipelago will be the same as that of the island group as a whole. Pigs may die out on one or two islands within an archipelago but not others, as appears to be the case in the Southern Cook Islands (see Table 1) (Allen et al. 2001; Kirch 2000b).

Finally, and perhaps most importantly, the analysis performed here is concerned first and foremost with ecological processes, not social ones, so marking culturally unified archipelagoes as single cases is specious. I do not intend to argue that culture is irrelevant to the phenomenon of pig extinction in Polynesian. It is possible that ecological processes influence cultural ones, which in turn affect pig survivorship. Biogeographic effects may thus operate indirectly through culture. Alternatively, cultural processes may override ecological ones. Island proximity, for example, may encourage human interaction between landmasses, creating a rescue effect for pigs in which smaller islands are buffered from extirpation by the continual reintroduction of animals. Unfortunately, relevant cultural factors, such as the interisland voyaging that may have facilitated pig introductions, are not easily quantifiable and are therefore difficult to test. They do represent intriguing avenues for future research, however.

Ultimately, if biogeographic factors are significant, whether their influence is direct or indirect, their effect should be measurable. If the effects of biogeography are mitigated by cultural activities, then it may be that island size matters less to pig survival in Polynesia than other variables not tested here.

\section{RESULTS}

I conducted a four-part statistical analysis to test the hypotheses that the likelihood of extinction for domestic pigs in Polynesia is correlated with island area, maximum island elevation, geologic type, latitudinal distance from the equator, and longitude east. The expectation is that if one or more of these variables is influential in pig survivorship, there should be a statistically significant correlation between these and pig extirpation. The statistical tests applied are a studentized t-test, a chi-square test, a logistic regression, and a bootstrap analysis. 
Table 2. Biography of Islands in Test Sample

\begin{tabular}{|c|c|c|c|c|c|c|c|}
\hline ISLAND GROUP & ISLAND & $\begin{array}{l}\text { FAUNAL } \\
\text { SCENARIO }\end{array}$ & $\begin{array}{l}\text { ISLAND } \\
\text { AREA } \\
\left(\mathrm{KM}^{2}\right)\end{array}$ & $\begin{array}{l}\text { ISLAND } \\
\text { TYPE }\end{array}$ & $\begin{array}{c}\text { ELEVATION } \\
\text { MASL }\end{array}$ & $\begin{array}{l}\text { LAT. FROM } \\
\text { EQUATOR }\end{array}$ & $\begin{array}{c}\text { LONGITUDE } \\
\text { EAST }\end{array}$ \\
\hline \multirow[t]{3}{*}{ Cook } & Mangaia & Extinction & 34.5 & volcanic \& coral & 169 & $21.94^{\circ}$ & $202.10^{\circ}$ \\
\hline & Rarotonga & Survival & 67.6 & volcanic \& coral & 653 & $21.23^{\circ}$ & $200.22^{\circ}$ \\
\hline & Aitutaki & Uncertain & 16.5 & volcanic & 124 & $18.88^{\circ}$ & $200.26^{\circ}$ \\
\hline \multirow[t]{4}{*}{ Gambier-Mangareva } & Akamaru & Extinction & 1.8 & volcanic & 243 & $23.13^{\circ}$ & $225.06^{\circ}$ \\
\hline & Aukena & Extinction & 1.3 & volcanic & 198 & $23.13^{\circ}$ & $225.10^{\circ}$ \\
\hline & Mangareva & Extinction & 13.0 & volcanic & 441 & $23.13^{\circ}$ & $225.08^{\circ}$ \\
\hline & Taravai & Extinction & 5.7 & volcanic & 243 & $23.13^{\circ}$ & $224.97^{\circ}$ \\
\hline \multirow[t]{8}{*}{ Hawai'i $i$} & Hawai'i & Survival & $10,434.0$ & volcanic & 4169 & $19.50^{\circ}$ & $204.50^{\circ}$ \\
\hline & Kaho'olawe & Survival & 113.3 & volcanic & 450 & $20.55^{\circ}$ & $203.35^{\circ}$ \\
\hline & Kaua'i & Survival & 1434.6 & volcanic & 1598 & $22.50^{\circ}$ & $200.50^{\circ}$ \\
\hline & Lāna“i & Survival & 358.4 & volcanic & 1027 & $20.85^{\circ}$ & $203.05^{\circ}$ \\
\hline & Maui & Survival & 1903.3 & volcanic & 3052 & $20.75^{\circ}$ & $203.75^{\circ}$ \\
\hline & Moloka'i & Survival & 677.9 & volcanic & 1515 & $21.15^{\circ}$ & $203.00^{\circ}$ \\
\hline & $\mathrm{Ni}^{6}$ ihau & Survival & 182.8 & volcanic & 390 & $21.90^{\circ}$ & $199.85^{\circ}$ \\
\hline & O'ahu & Survival & 1583.3 & volcanic & 1227 & $21.50^{\circ}$ & $202.05^{\circ}$ \\
\hline \multirow[t]{3}{*}{ Marquesas } & Nuku Hiva & Survival & 345.0 & volcanic & 1186 & $8.95^{\circ}$ & $219.75^{\circ}$ \\
\hline & Tahuata & Survival & 70.8 & volcanic & 1000 & $9.93^{\circ}$ & $228.10^{\circ}$ \\
\hline & Ua Huka & Survival & 82.4 & volcanic & 856 & $8.92^{\circ}$ & $220.44^{\circ}$ \\
\hline \multirow[t]{2}{*}{ Pitcairn } & Henderson & Extinction & 37.3 & raised atoll & 33 & $24.42^{\circ}$ & $231.68^{\circ}$ \\
\hline & Pitcairn & Extinction & 4.2 & volcanic & 347 & $25.50^{\circ}$ & $229.87^{\circ}$ \\
\hline \multirow[t]{3}{*}{ American Samoa } & Ofu & Survival & 7.5 & volcanic & 494 & $14.19^{\circ}$ & $190.35^{\circ}$ \\
\hline & Olosega & Survival & 5.4 & volcanic & 639 & $14.19^{\circ}$ & $190.38^{\circ}$ \\
\hline & $\mathrm{Ta}^{6} \mathrm{u}$ & Survival & 45.7 & volcanic & 965 & $14.25^{\circ}$ & $190.53^{\circ}$ \\
\hline \multirow[t]{3}{*}{ Western Samoa } & Manono & Survival & 2.9 & volcanic & 91 & $13.83^{\circ}$ & $187: 92^{\circ}$ \\
\hline & Savai'i & Survival & 1717.6 & volcanic & 1858 & $13.60^{\circ}$ & $187.55^{\circ}$ \\
\hline & ‘Upolu & Survival & 1125.1 & volcanic & 1143 & $13.95^{\circ}$ & $188.30^{\circ}$ \\
\hline \multirow[t]{4}{*}{ Society } & Huahine & Survival & 82.1 & volcanic & 669 & $16.72^{\circ}$ & $208.90^{\circ}$ \\
\hline & Mo'orea & Survival & 132.0 & volcanic & 1207 & $17.57^{\circ}$ & $210.00^{\circ}$ \\
\hline & Tahiti & Survival & 1068.8 & volcanic & 2241 & $17.63^{\circ}$ & $210.50^{\circ}$ \\
\hline & Teti'aroa & Survival & 12.8 & atoll & 3 & $17.00^{\circ}$ & $210.43^{\circ}$ \\
\hline
\end{tabular}




\begin{tabular}{lllrlrr} 
Solomon & Anuta & Extinction & 2.6 & volcanic & 65 & $11.68^{\circ}$ \\
& Bellona & Extinction & 11.0 & raised atoll & 91 & $16.30^{\circ}$ \\
Tikopia & Extinction & 5.0 & volcanic & 376 & $159.74^{\circ}$ \\
Tonga & Niuatoputapu & Survival & 15.6 & volcanic & 146 & $18^{\circ}$ \\
Vanuatu & Malo & Survival & 180.0 & volcanic \& coral & 326 & $15.96^{\circ}$ \\
\hline
\end{tabular}

Figures for island area, geologic type, elevation, and latitude and longitude are based on data from the United Nations Environment Programme Island Directory, operational navigational charts published by the United States and Australian governments, and Freifeld et al. (2001). 
TABLE 3. T-Test

\begin{tabular}{lcccrr}
\hline VARIABlE* & $\mathrm{T}^{* *}$ & $p$ (TWO-TAILED) & CASE & MEAN & STANDARD DEVIATION \\
\hline Area & 2.054 & 0.052 & Survival & 902.04 & 2123.52 \\
& & & Extinction & 11.64 & 13.35 \\
Latitude & -1.589 & 0.136 & Survival & 16.76 & 4.14 \\
& & & Extinction & 19.95 & 5.76 \\
Longitude east & -0.580 & 0.574 & Survival & 200.70 & 13.25 \\
Maximum elevation & \multirow{2}{*}{4.479} & \multirow{2}{*}{$<0.001$} & Extinction & 206.23 & 28.91 \\
& & & Survival & 1121.04 & 961.60 \\
& & & Extinction & 220.60 & 137.06 \\
\hline
\end{tabular}

$* \mathrm{n}=34, \mathrm{n}_{\mathrm{s}}=24, \mathrm{n}_{\mathrm{e}}=10$, where $\mathrm{s}=$ survival and $\mathrm{e}=$ extinction.

** Equal variances not assumed.

I began statistical assessment of the dataset by dividing the 34 island cases, based on the European contact presence/absence data, into subsets representing instances of pig survival $\left(n_{s}=24\right)$ and instances of extirpation $\left(n_{e}=10\right)$. As an initial exploratory measure, I employed a studentized t-test to assess the difference between the mean of island area, latitude, longitude, and elevation for all instances of extirpation and all instances of survival. Table 3 summarizes the resultant data for each of these four variables. There is no significant difference in the mean latitude for those islands where pigs survive and those where they become extirpated, suggesting that differences in tropical and subtropical climates are not affecting the success of pig husbandry. Likewise, there is no statistically significant difference in mean longitude east for cases of extinction and survival. This result was not unexpected given the oversimplification of a pig species-isolation model that relies solely on linear distance from a source of dispersal and excludes the more complex cultural variables that structure isolation for human communities and their domesticated animals. Since both latitude and longitude demonstrated no correlation with pig survivorship, these variables were dropped from further analysis. There was, however, a statistically significant difference in the mean area of islands where pigs die out and those where they persist through time $(t=2.054, p=0.052)$. This would not be expected if large islands experienced pig extirpation just as frequently as small. Islands where pigs survive are an average of $902.04 \mathrm{~km}^{2}$ in extent, while those on which they die out are a mere 11.64 $\mathrm{km}^{2}$. The t-test for island elevation also revealed a significant relationship between survivorship and the maximum height of an island above sea level $(\mathrm{t}=4.479, p<0.001)$. Here again, there is a significant disparity between the mean for islands where pigs persist (1121.04 mASL) and where they die out (220.60 mASL). It appears, therefore, that both the area and elevation of an island are correlated with pig survivorship suggesting the influence of ecological factors on the success of animal husbandry in Polynesia. Possible collinearity between island area and island elevation, however, makes this relationship problematic. I will take up this issue later; for now, I turn to the fifth and final variable under consideration-island geology.

Because island geologic type is a nominal variable, I employed a chi-square test to determine whether observed instances of pig extinction and survival matched 
Table 4. Chi-Square Test: Island Geologic Type Cross-Tabulation

\begin{tabular}{lllccc}
\hline & & & \multicolumn{2}{c}{ CASE } & \\
\cline { 4 - 6 } & & & survival & ExTinction & TOTAL \\
\hline Island geologic type & Volcanic & Observed & 21 & 7 & 28 \\
& & Expected & 19.8 & 8.2 & 28.0 \\
& Other & Observed & 3 & 3 & 6 \\
& & Expected & 4.2 & 1.8 & 6.0 \\
& Total & Observed & 24 & 10 & 34 \\
& & Expected & 24.0 & 10.0 & 34.0 \\
\cline { 3 - 6 } & Value & $p$ (2-sided) & & & \\
\hline Pearson $\chi^{2}$ & 1.488 & 0.223 & & & \\
Fisher's exact test & & 0.328 & & & \\
\hline
\end{tabular}

expected distributions across island geologic type (atoll, raised atoll, volcanic, and volcanic-coral mix). If geology plays a role in island productivity, then we should expect that Polynesian pig husbandry would be favored on the more fertile volcanic islands and be less so on islands of coral/limestone substrate or mixed volcaniccoral geology. That is, instances of extinction should cluster around atolls, makateas, and mixed geology islands. The dominance of the sample by volcanic islands-which account for 28 cases, or 82.4 percent of the sample-means that the minimum number of observations (i.e., cases) required to make the chi-square test sufficiently sensitive to differences in observed and expected frequencies is lacking for the other three island types. Atolls are represented in the dataset by a single case (Teti'aroa, survival), raised atolls are represented by just two cases (Bellona, extinction; Henderson, extinction), and islands of geologically mixed types amounted to three cases of the sample (Malo, survival; Mangaia, extinction; Rarotonga, survival). Sample size here is too small to effectively test the relationship between extinction and each of the four island types. I therefore collapsed the geologic types into two categories, "volcanic" and "other," the latter of which groups the six islands that are not strictly volcanic. The results of the chi-square analysis, summarized in Table 4, showed no significant correlation between island type and where pigs survive or die out (Pearson's $\chi^{2}=1.488, p=0.223$; $p=0.328$, Fisher's exact test). These results are not unexpected given that the number of cases representing nonvolcanic islands is small. Of the six islands that are not strictly volcanic, three (50.0 percent) underwent pig extinction and another three (50.0 percent) experienced pig survival. Pigs survived on 21 (75.0 percent) of the volcanic islands and became extinct on the remaining 7 (25.0 percent) of the volcanic islands. A larger sample size might reveal a relationship between pig survivorship and island type, but based on the available data it does not appear that geology is a variable in Polynesian pig extinction.

Of the five ecological variables considered here, only two-island area and elevation-demonstrated a significant correlation to pig extirpation. To further evaluate the relationship between area, elevation, and pig extinction, I employed a binary logistic regression, treating area and elevation as separate independent variables; results are summarized in Tables $5 \mathrm{a}$ through $5 \mathrm{e}$. This analysis confirms 
Table 5a. Logistic Regression: Area and Pig Survivorship

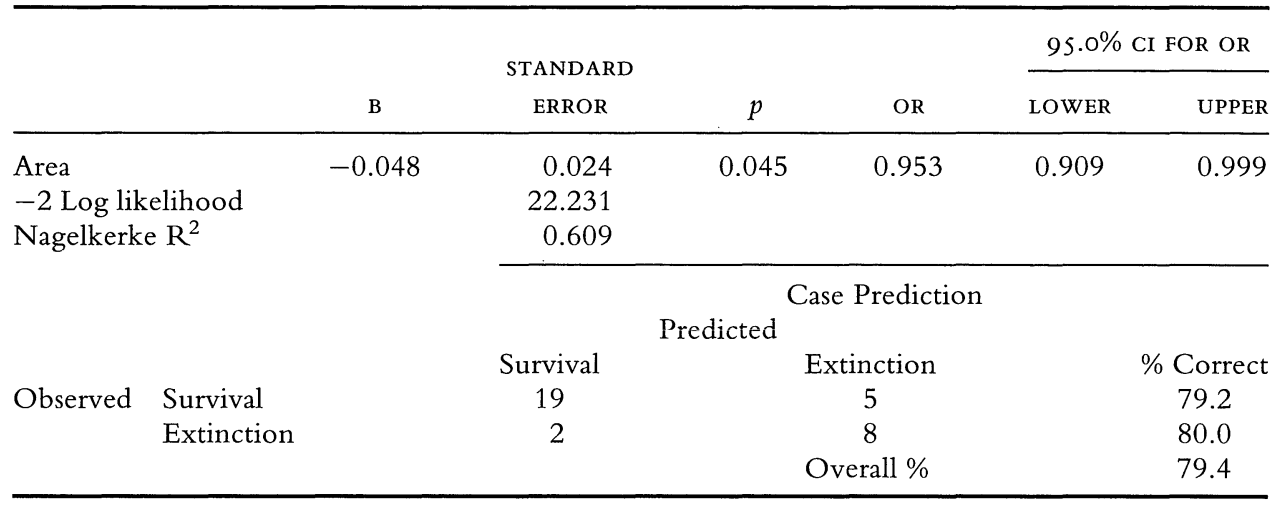

Table 5B. Logistic Regression: Maximum Elevation and Pig Survivorship

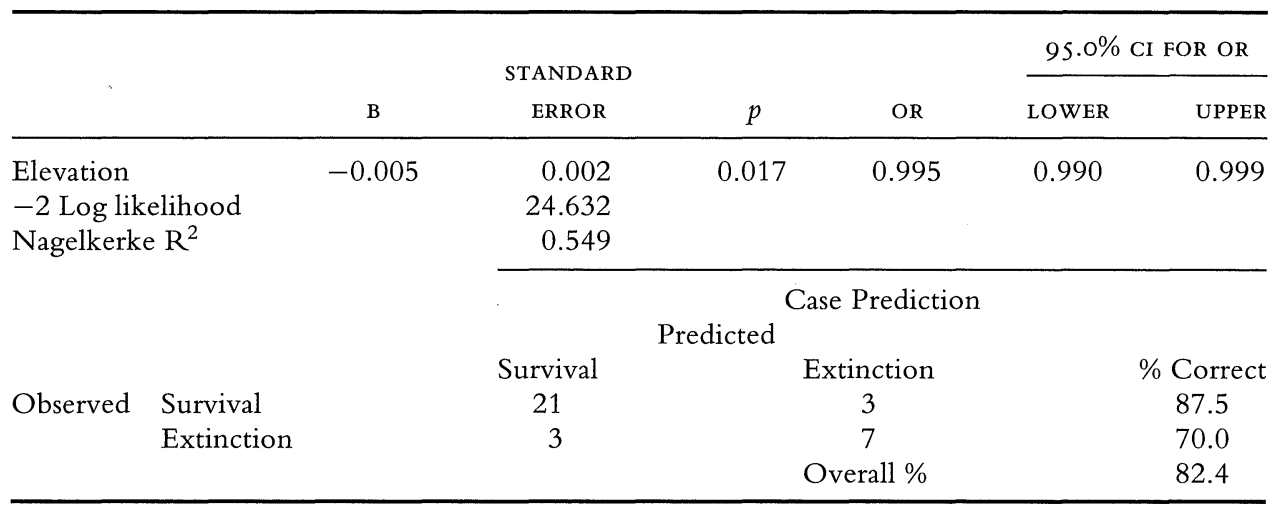

Table 5C. Change in Odds and Probability for Pig Extinction Associated with a Change in Island Area

\begin{tabular}{rccc}
\hline AREA KM $^{2}$ & ODDS OF EXTINCTION & PROBABILITY OF EXTINCTION & CHANGE IN PROBABILITY \\
\hline 1.00 & 2.759 & 0.7340 & \\
2.00 & 2.630 & 0.7245 & -0.0095 \\
11.64 & 1.656 & 0.6235 & -0.1011 \\
445.20 & $1.517 \mathrm{E}-09$ & $1.5170 \mathrm{E}-09$ & $-6.2346 \mathrm{E}-01$ \\
902.04 & $4.546 \mathrm{E}-19$ & $4.5462 \mathrm{E}-19$ & $-1.5170 \mathrm{E}-09$ \\
\hline
\end{tabular}

Mean area of islands experiencing pig extinction $=11.64 \mathrm{~km}^{2}$; mean area of islands where pigs survive $=902.038 \mathrm{~km}^{2}$; midpoint between the means for extinction and survival $=445.20 \mathrm{~km}^{2}$.

the results of the initial t-test. The coefficient for island area is significant (odds ratio 0.953, $p=0.045$, 95 percent CI 0.909, 0.999, Nagelkerke $\mathrm{R}^{2}=0.609$ ), confirming a correlation between decreasing island area and increasing likelihood of extinction for pigs in Polynesia. The case prediction breakdown (Table 5a) reveals that in this sample, island size accurately predicts survival and extinction nearly 80 percent of the time. Table $5 \mathrm{c}$ lists the changes in odds and probability 
Table 5D. Change in Odds and Probability for Pig Extinction Associated With a Change in Island Elevation

\begin{tabular}{cccc}
\hline ELEVATION MASL & ODDS OF EXTINCTION & PROBABILITY OF EXTINCTION & CHANGE IN PROBABILITY \\
\hline 1.00 & 4.683 & 0.8240 & \\
2.00 & 4.660 & 0.8233 & -0.0007 \\
11.00 & 4.455 & 0.8167 & -0.0066 \\
220.60 & 1.562 & 0.6097 & -0.2136 \\
450.22 & 0.496 & 0.3313 & -0.2783 \\
1121.04 & 0.017 & 0.0170 & -0.3143 \\
\hline
\end{tabular}

Mean elevation of islands experiencing pig extinction $=220.60 \mathrm{~m}$; mean elevation of islands where pigs survive $=1121.04 \mathrm{~m}$; midpoint between the means for extinction and survival $=450.22 \mathrm{~m}$.

Table 5e. Logistic Regression: Maximum Elevation, Area, and Pig Survivorship

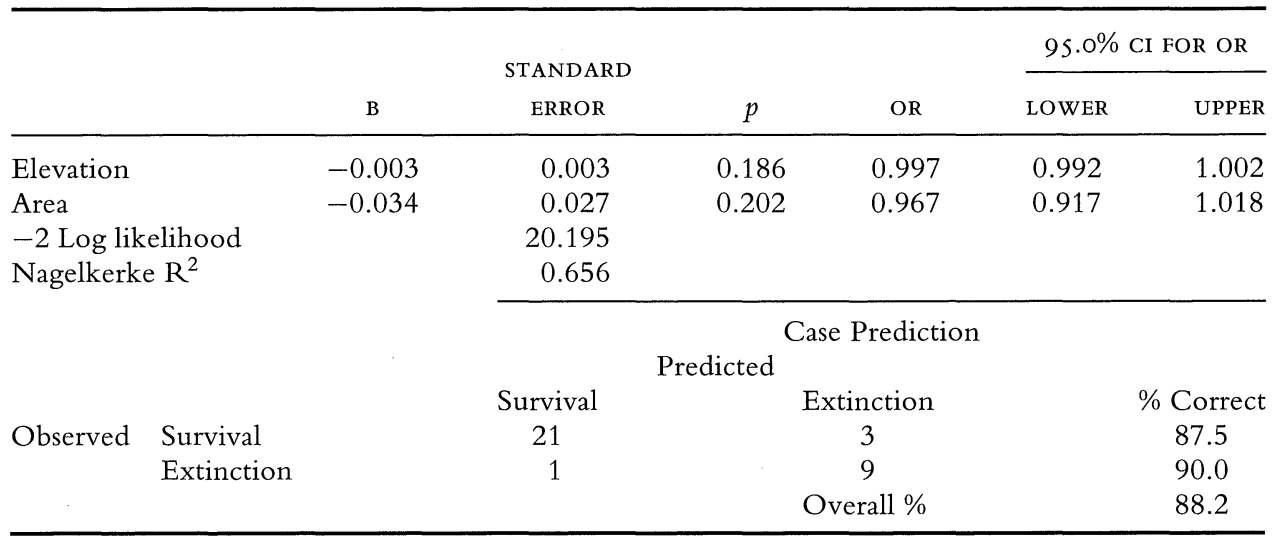

of extinction associated with a change in area for an island of a given size. Statistical analysis based on the odds ratio indicates that for an island of $1 \mathrm{~km}^{2}$, an area increase of a single square kilometer reduces the probability of pig extinction from 73.4 percent to 72.5 percent. For an island of $902.04 \mathrm{~km}^{2}$, the mean area for islands representing pig survival, the associated probability of extinction is so small that it is essentially 0.0 percent.

Logistic regression of island elevation and pig survivorship also indicates a significant correlation between elevation and the likelihood of pig extinction (odds ratio 0.995, $p=0.017$, 95 percent CI 0.990, 0.999, Nagelkerke $\mathrm{R}^{2}=0.549$ ); here, elevation correctly predicted extinction or survival for more than 82 percent of cases (Table 5b). The changes in odds and probability of extinction associated with a change in elevation for an island of a given height are listed in Table $5 \mathrm{~d}$. For an island elevated $1 \mathrm{~m}$ above sea level, a $1-\mathrm{m}$ increase in elevation reduces the probability of pig extinction from 82.4 percent to 82.3 percent. A $10-\mathrm{m}$ elevation gain reduces this probability to 81.7 percent.

Although the majority of cases are correctly predicted in this analysis, some 18-20 percent are misclassified by the logistic regression models for area (seven misclassified) and elevation (six misclassified). Either extinction is predicted for the island but pigs survive, or survival is predicted but pigs become extinct. Analysis of these residual cases suggests possible explanations for some of the misclas- 
sifications but not all. Both the area and elevation models incorrectly predict extinction for three of the same islands: Teti'aroa, Manono, and Niuatoputapu. Yet on each of these relatively small, relatively low-lying islands, pigs survive over time. It could be that human interaction within the larger island groups of each of these islands reintroduced pigs on multiple occasions, preventing their wholesale disappearance. Manono Island, for example, is easily reached from 'Upolu, a large, high volcanic island lying roughly $4 \mathrm{~km}$ to the east and one of the two large islands in western Samoa where pigs survive over time. A similar explanation might account for pig survival on Ofu and Olosega, which are sufficiently small for the area model to predict extinction but lie within sight of $\mathrm{Ta}^{c} \overline{\mathrm{u}}$, a significantly larger volcanic island less than $20 \mathrm{~km}$ away on which pigs also survive. The small, low volcanic island of Niuatoputapu is more isolated, but archaeological research indicates its residents were integrated into a larger regional exchange network under the Tongan Maritime Chiefdom, and this system may have sustained pig husbandry in the island's later prehistory (Kirch 1988). On Henderson, where pigs are predicted to survive based on the island's relatively large size, and on Pitcairn, where pigs are expected to survive based on its relatively high elevation, pig husbandry ultimately fails in each case. Both islands, of course, were abandoned by their human occupants some time before the historic period (Anderson 2001). This makes inevitable the negative outcome of pig husbandry for Pitcairn and Henderson, although pigs themselves could theoretically have survived on their own had circumstances favored it.

For the remaining misclassified cases-Mangaia, where the area model predicts survival, and Mangareva and Tikopia, where the elevation model predicts survival-it is unclear what might account for the disparity between observed and expected survivorship scenarios. Mangaia, Tikopia, and the Mangareva group (throughout which pigs became extinct) are all relatively isolated. It may be that the lack or diminishment of cultural interaction between these islands and others put pig husbandry at a disadvantage. Or it may be that disease or cyclones claimed pig populations. This is simply speculation, however; any of a number of possible cultural or ecological factors may have played a role in pig extinction on these islands. Explaining the exceptional instances where pigs become extinct on relatively large, high islands must be a focus of future investigation.

Island area and elevation were also tested for their combined effect in relation to pig extinction (Table 5e). A multiple logistic regression model of these two covariates, however, yields insignificant results (odds ratio [elevation] 0.997, $p=0.186,95$ percent CI 0.992, 1.002; odds ratio [area] 0.967, $p=0.202,95$ percent CI 0.917, 1.018; Nagelkerke $\mathrm{R}^{2}=0.656$ ). The beta coefficients for island area and elevation above sea level are not statistically different from 1, indicating that no significant increase or decrease in the odds of pig extinction accompanies a change in island area and elevation.

Both island area and elevation, when tested individually, demonstrated a significant relationship to pig survivorship, but here no such relationship can be detected. This outcome can be attributed to two problems. First, introducing a second covariate to the logistic regression model brings about the loss of an additional degree of freedom that the sample size of the dataset is too small to accommodate. The second problem involves the issue of collinearity between elevation and area. 
As discussed earlier, the possible correlation between the independent variables of island area and island elevation introduces a confounding factor to this analysis. Obviously, islands with the same extent of shoreline but different elevations will have different areas, the higher island being larger. To test for possible collinearity, I regressed island area against elevation, using the base $10 \mathrm{log}$ of each variable to correct for curvilinearity. The regression model is significant $(F=26.379$, $p<0.001, \mathrm{R}=0.672$ ) indicating that area is in fact correlated with elevation, with 45.2 percent of the variation in island area being explained by island elevation. This problem of collinearity contributes to the insignificance of the multivariate logistic regression model. For highly correlated covariates, a large dataset is required to independently identify the beta coefficients, because each observation is in effect contributing only a small proportion of an observation to identifying the difference between each beta parameter. Given these issues and the small size of the dataset, evaluating the relative effect of area and elevation is problematic. Which variable is the better predictor of pig extinction-elevation or area?

To address this question and overcome the limitations of small sample size, I employed a nonparametric bootstrap analysis of the original dataset of 34 island cases. The bootstrap analysis produces a nonparametric sampling distribution for each parameter of the model through resampling of the original dataset (Efron and Tibshirani 1993). The sampling distribution may then be employed to determine whether the parameter estimate excludes 0 (no effect) with a specified probability. The island dataset was sampled with replacement 1001 times. The 1001 parameters were sorted and the central 95 percent limits determined, yielding a nonparametric 95 percent confidence interval around the median (Table 6). The results show that the estimate for $b_{\text {area }}$ is significantly different from 0 , while that of $b_{\text {elevation }}$ is not. Bootstrap analysis thus indicates that island area is a better predictor of pig survivorship.

The results obtained through this set of statistical analyses support a correlation between island size and the likelihood of extirpation for the Polynesian pig. Elevation also exhibits a correlation with the failure of pig husbandry, although bootstrap analysis suggests that it is not as good a predictor variable as island area. Other variables - island geologic type, longitude, and latitude-exhibit either an insignificant or inconclusive relationship to pig survivorship over time. It appears that prehistoric pigs on larger islands may have fared better than their small-island counterparts. Most intriguingly, it seems that the ecological principles underlying the species-area relationship may apply just as readily to domesticated animals as they do wild ones.

Table 6. Bootstrap Summary

\begin{tabular}{lcrc}
\hline & & \multicolumn{2}{c}{$95.0 \% \mathrm{CI}$} \\
\cline { 3 - 4 } & ESTIMATE & LOWER & UPPER \\
\hline $\mathrm{b}_{0}$ & 1.942 & 17.732 & 0.124 \\
$\mathrm{~b}_{\text {area }}$ & 0.041 & 0.012 & 0.475 \\
$\mathrm{~b}_{\text {elevation }}$ & 0.003 & -0.005 & 0.032 \\
\hline
\end{tabular}




\section{DISCUSSION AND CONCLUSION}

This analysis supports an island biogeographic explanation for pig extinction in prehistoric Polynesia. Island size is significantly associated with pig survivorship in the South Pacific, at least for the cases examined here. A larger sample of islands with a known record of pig habitation might produce a more powerful test, but at present it appears that island biogeographic factors have, at least in part, shaped the prehistoric distribution of pigs in the South Pacific.

While island elevation is correlated with pig extinction, statistical analyses indicate that it is not as good a predictor variable as island area. Other factors not directly tested here might also covary with island area, including habitat composition and diversity. However, island area may serve as a general proxy for these variables since all are tied to species richness in various ways. It appears that the other ecological variables tested with relevance to the species-area relationshiplatitude and geologic type-do not demonstrate this relationship within this dataset. Longitude, a crude distance measure of isolation, shows no relationship to pig extinction. However, since pigs in Oceania were domesticated animals under human control, isolation in Polynesia is more properly reckoned as a cultural variable with components that include the timing, degree, and nature of human interaction between islands. Interisland voyaging could have facilitated the reintroduction of pigs in some places and may account for the presence of pigs on islands on which they are predicted to go extinct. For example, although pigs eventually were extirpated on Anuta, ethnohistoric data indicate that at some time in the past, Anutans had obtained pigs from the neighboring island of Tikopia (Yen and Gordon 1973).

It is difficult to establish the precise effect of cultural variables; these are not easily quantifiable given the complexities of Polynesian prehistory and island interaction. Importantly, however, the results of this analysis suggest that for the cases examined here, cultural variables-whether these are socioreligious incentives to maintain pigs, interaction between islands, or other factors-do not contravene the full effect of island size on pig survivorship. Indeed, since some cultural variables may covary with biogeographic ones, it may be that the probability of extirpation is a function of island area effects as regulated by human activities. For instance, the human decision to exterminate pigs or let them die out may be driven by the practical considerations of Polynesian peoples in light of such concerns as resource limitations-particularly the availability of arable land and agricultural productivity. This suggests that some processes, such as trophic competition between humans and pigs, may have functioned in tandem with island area to drive these domesticates to extinction when critical resource thresholds were breached. In this respect, one can consider ecological influences as being mediated by social mechanisms in the form of husbandry management strategies.

In a broader view, the results obtained here have implications for domesticated mammals in other island contexts. The effects of island biogeography may be applicable to other mammalian domesticates and may explain cases of island extirpation of domestic mammals elsewhere in the world, although at present it appears that Oceania may be unique in this respect. If so, island biogeographic forces may not only govern "natural" ecological relationships but might also provide 
a powerful explanatory framework for a very exceptional set of organismsdomesticated mammals.

\section{ACKNOWLEDGEMENTS}

I would like to thank Don Grayson for his considerable support and guidance in the research and writing of this paper. Darryl Holman offered invaluable statistical assistance. Peter Lape and Thegn Ladefoged provided insightful comments on an earlier draft. I thank Melinda Allen, Lisa Nagaoka, and Marc Munro for their help along the way.

\section{NOTES}

1. Ethnographic work on pig husbandry illustrates this energetic relationship well. In his study of Tsembaga pig rearing in New Guinea, Rappaport (1968:61-63) estimates that approximately 0.15 acres of land were put under taro and yam cultivation for each pig in the herd, roughly the same amount allotted to each human. For the Tsembaga, this ultimately meant that the ratio of energy they derived from pork to that which they expended in raising pigs was on the order of somewhere between $2: 1$ and $1: 1$. In economic terms, production systems such as this, in which energy returns only just match energy inputs, are not efficient and likely exist for reasons other than simple caloric incentives. Rappaport suggests that the true value of pigs in New Guinea may have been not in their role as a calorie storage unit for the investment of agricultural surplus, but rather as a nutrient converter for the production of fat and protein. Pig husbandry in Polynesia may have functioned in a similar capacity.

2. Freeing pigs and allowing them to forage for themselves may have been just as problematic. Free-ranging pigs could have destroyed gardens, disrupted agro-forest, and harmed populations of native plants and animals upon which the Polynesians also depended (Green and Weisler 2004).

3. To properly gauge island isolation in a model with both biogeographic and cultural components, it would be necessary to account in detail for (1) the route(s) of human colonization of the $\mathrm{Pa}$ cific; (2) subsequent interaction between islands (to provide for the possibility of multiple pig introductions); (3) the number of islands involved in persistent contact; (4) the distance between these islands; and (5) which of these islands supported pig populations. Additionally, an understanding of which island was the source for the pig populations of another would be needed to properly account for pig dispersal routes. Not only must all these factors be integrated, but the timing of their occurrence must also be incorporated so that any reliable isolation model of pig distribution has both spatial and temporal components.

4. The reliability of early historic accounts is always open to question in analyses such as this. In the absence of other data, however, ethnohistoric sources constitute the only means by which such assessments can be made. In the instances where the archaeological record for pig presence/ absence is known to conflict with the reports provided by early Europeans, these cases have been removed from analysis.

5. One equivocal case, that of Aitutaki, was not included in testing here because of conflicting archaeological and ethnographic data (see Table 1). Early European accounts (Williams 1837:8283; Bligh 1969:147) report the absence of pigs on Aitutaki in the Cook Islands, and subsequent publications have followed this characterization (e.g., Bay-Petersen 1983; Bellwood 1978; Buck 1944). While it is possible that pigs on Aitutaki were extirpated in the late-prehistoric or early historic period, thus giving rise to the ethnohistoric accounts, Allen (personal communication, 2003) believes that this may place too much reliance on somewhat uncertain reports. More significantly, however, pig extirpation does not appear to be borne out by the zooarchaeological record for the island, which indicates the presence of pigs throughout the prehistoric sequence and persisting into the early historic period (Allen 1992). In light of this ambiguity, Aitutaki has been omitted from the principal analysis above.

\section{REFERENCES}

Allen, M. S.

1992 Dynamic Landscapes and Human Subsistence: Archaeological Investigation of Aitutaki Island, Southern Cook Islands. Ph.D. diss. University of Washington, Seattle. 
Allen, M. S., E. Matisoo-Smith, And A. Horsburgh

2001 Pacific "babes": Issues in the origins and dispersal of Pacific pigs and the potential of mitochondrial DNA analysis. International Journal of Osteoarchaeology 11:4-13.

Anderson, A.

2001 No meat on that beautiful shore: The prehistoric abandonment of subtropical Polynesian islands. International Journal of Osteoarchaeology $11: 14-23$.

2002 Faunal collapse, landscape change and settlement history in Remote Oceania. World Archaeology 33:375-390.

BAy-Petersen, J.

1983 Competition for resources: The role of pig and dog in the Polynesian agricultural economy. Journal de la Société des Océanistes 77:121-129.

BEECHEY, F. W.

1968 Narrative of a Voyage to the Pacific and Beering's Strait, vol. 1. New York: De Capo Press.

BellwoOd, P.

1978 Archaeological Research in the Cook Islands. Pacific Anthropological Records 27. Honolulu: Department of Anthropology, Bernice P. Bishop Museum.

1987 The Polynesians: Prehistory of an Island People. London: Thames and Hudson.

Bligh, W.

1969 A Voyage to the South Sea and around the World in the Years 1708 to 1711. Amsterdam: De Capo Press.

Brown, J. H., ANd A. Kodric-Brown

1977 Turnover rates in insular biogeography: Effect of immigration on extinction. Ecology $58(2): 445-449$.

Brown, J. H., AND M. V. Lomolino

1998 Biogeography, 2nd ed. Sunderland, MA: Sinauer Associates.

BRYAN, B. A.

1915 Natural History of Hawaii. Honolulu: Hawaiian Gazette Co.

Buck, P. H.

1938a Vikings of the Pacific. Chicago: University of Chicago Press.

1938 b Ethnology of Mangareva. Bernice P. Bishop Museum Bulletin 157. Honolulu: Bernice P. Bishop Museum.

1944 Arts and Crafts of the Cook Islands. Bernice P. Bishop Bulletin 179. Honolulu: Bernice P. Bishop Museum.

Clarke, C.M.H., and R. M. Dzieciolowski

1991a Feral pigs in the northern South Island, New Zealand: I. Origin, distribution, and density. Journal of the Royal Society of New Zealand 21(3):237-247.

1991b Feral pigs in the northern Souch Island, New Zealand: II. Breed composition of present populations. Journal of the Royal Society of New Zealand 21(3):249-260.

Conte, E.

2002 Current research on the island of Ua Huka, Marquesas archipelago, French Polynesia. Asian Perspectives 41(2): 258-268.

Cordy, R., J. Tainter, R. Renger, And R. Hitchcock

1993 Archaeology of Kaloko: A generalized model of a Hawaiian community's social organization and adaptation. Hawaiian Archaeology 2:28-49.

Cox, P. A., And S. A. Banack, eds.

1991 Islands, Plants, and Polynesians: An Introduction to Polynesian Ethnobotany. Portland, OR: Dioscorides Press.

Cram, C. L.

1975 Prehistoric fauna and economy in the Solomon Islands, in Maritime Adaptations of the Pacific: 247-253, ed. R. W. Casteel and G. I. Quimby. The Hague: Mouton.

Crosby, A. W.

1986 Ecological Imperialism: The Biological Expansion of Europe, 900-1900. Cambridge: Cambridge University Press. 
Davidson, J. M.

1969 Excavation of a coastal midden deposit, SU-Lo-1, in Archaeology in Western Samoa, vol. $1: 224-252$, ed. R. C. Green and J. M. Davidson. Bulletin of the Auckland Institute and Museum No. 6. Auckland: Auckland Institute and Museum.

1984 The Prehistory of New Zealand. Auckland: Longman Paul.

Dye, T., AND D. W. Steadman

1990 Polynesian ancestors and their animal world. American Scientist 78:207-215.

EFron, B., AND R. Tibshirani

1993 An Introduction to the Bootstrap. New York: Chapman \& Hall.

ELLIS, W.

1829 Polynesian Researches during a Residence of Nearly Six Years in the South Sea Islands. London: Fisher, Son, \& Jackson.

EMORY, K. P.

1975 Material Culture of the Tuamotu Archipelago. Pacific Anthropological Records 22. Honolulu: Department of Anthropology, Bernice P. Bishop Museum.

1979 The Societies, in The Prehistory of Polynesia: 200-221, ed. J. D. Jennings. Cambridge: Harvard University Press.

1986 Kapingamarangi: Social and Religious Life of a Polynesian Atoll. Bernice P. Bishop Museum Bulletin 228. Millwood, NY: Kraus Reprint.

FIRTH, R.

1959 Social Change in Tikopia: Re-Study of a Polynesian Community after a Generation. London: George Allen \& Unwin.

FORSTER, G.

1777 A Voyage Round the World ... Resolution, Commanded by Captain James Cook, vol. 1. London: B. White.

Freifeld, H. B., D. W. Steadman, and J. K. Sailerb

2001 Landbirds on offshore islands in Samoa. Journal of Field Ornithology 72:72-85.

Green, R. C.

1979 The Lapita, in The Prehistory of Polynesia: 27-60, ed. J. D. Jennings. Cambridge: Harvard University Press.

Green, R. C., ANd M. I. Weisler

2004 Prehistoric introduction and extinction of animals in Mangareva, southeast Polynesia. Archaeology in Oceania 39:34-41.

Groves, C.

1983 Pigs east of the Wallace Line. Journal de la Société des Océanistes 77:105-119.

GunNess, J. L.

1993 The Kualoa archaeological project. Hawaiian Archaeology 2:50-70.

HENRY, T.

1928 Ancient Tahiti. Bernice P. Bishop Museum Bulletin 48. Honolulu: Bernice P. Bishop Museum.

Hogbin, I.

1971 Polynesian ceremonial gift exchanges, in Polynesia: Readings on a Culture Area: 27-45, ed.

A. Howard. Scranton, NY: Chandler Publishing Company.

Hunt, T. L., AND P. V. Kirch

1987 An Archaeological Reconnaissance of the Manu'a Islands, American Samoa. Final report prepared for Historic Preservation Office and Coastal Zone Management Office. Seattle: Government of American Samoa.

JANETSKI, J. C.

1980 Analysis of dietary remains from Potusa and Falemoa, in Archaeological Excavations in Western Samoa: 117-122, ed. J. D. Jennings and R. N. Holmer. Pacific Anthropological Records 32. Honolulu: Department of Anthropology, Bernice P. Bishop Museum.

KaEPPler, A. L., ED.

1978 Cook Voyage Artifacts in Leningrad, Berne and Florence Museums. Honolulu: Bishop Museum Press. 
Kelly, M., and J. T. Clark

1980 Kawainui Marsh, O'ahu: Historical and Archaeololgical Studies. Departmental Reports Series of the Bernice P. Bishop Museum, Report 80-3. Honolulu: Department of Anthropology, Bernice P. Bishop Museum.

KIRCH, P. V.

1979 Marine Exploitation in Prehistoric Hawai'i: Archaeological Investigations at Kalāhuipua'a, Hawai $i$ Island. Pacific Anthropology Records 29. Honolulu: Department of Anthropology, Bernice P. Bishop Museum.

1984 The Evolution of the Polynesian Chiefdoms. Cambridge: Cambridge University Press.

1985 Feathered Gods and Fishhooks. Honolulu: University of Hawai'i Press.

1988 Niuatoputapu: The Prehistory of a Polynesian Chiefdom. Thomas Burke Memorial Washington State Museum Monograph No. 5. Seattle: Burke Museum.

1991 Polynesian agricultural systems, in Islands, Plants, and Polynesians: 113-133, ed. P. A. Cox and S. A. Banack. Portland, OR: Diasocrides Press.

2000a On the Road of the Winds: An Archaeology History of the Pacific Islands before European Contact. Berkeley: University of California Press.

2000 b Pigs, humans and trophic competition on small Oceanic islands, in Australian Archaeologist. Collected Papers in Honour of Jim Allen: 427-439, ed. A. J. Anderson and T. Murray. Centre for Archaeological Research and Department of Anthropology and Natural History. Canberra: Australian National University with the Department of Archaeology, La Trobe University, Coombs Academic Publishing.

Kirch, P. V., AND J. Ellison

1994 Palaeoenvironmental evidence for human colonization of remote Oceanic islands. Antiquity 68:310-322.

KirCH, P. V., AND T. L. Hunt, EDS.

1988 Archaeology of the Lapita Cultural Complex: A Critical Review. Thomas Burke Memorial Washington State Museum Research Report No. 5. Seattle: Burke Museum.

1993 The To'aga Site: Three Millennia of Polynesian Occupation in the Manu'a Islands, American Samoa. Contributions of the University of California Archaeological Research Facility No. 51. Berkeley: University of California, Archaeological Research Facility.

KIRCH, P. V., AND S. J. O'DAY

2003 New archaeological insights into food and status: A case study from pre-contact Hawaii. World Archaeology 34(3): 484-498.

Kirch, P. V., AND D. E. Yen

1982 Tikopia: The Prehistory and Ecology of a Polynesian Outlier. Bernice P. Bishop Museum Bulletin 238. Honolulu: Bishop Museum Press.

LADEFOGED, T. N.

1995 The evolutionary ecology of Rotuman political integration. Journal of Anthropological Archaeology 14(4):341-358.

LEACH, F., AND G. WARD

1981 Archaeology on Kapingamarangi Atoll: A Polynesian Outlier in the Eastern Caroline Islands. Dunedin: Department of Anthropology, University of Otago. (Privately published by B. F. Leach.)

LuOMala, K.

1960a The native dog in the Polynesian system of values, in Culture in History: Essays in Honor of Paul Radin: 190-240, ed. S. Diamond. New York: Columbia University Press.

$1960 \mathrm{~b}$ A history of the binomial classification of the Polynesian native dog. Pacific Science $14: 193-223$.

MacArthur, R. H., AND E. O. Wilson

1963 An equilibrium theory of insular zoogeography. Evolution $17: 373-387$.

1967 The Theory of Island Biogeography. Princeton: Princeton University Press.

Matisoo-Smith, E.

2001 Molecular archaeology of Pacific commensals: Animal models for human migrations. American Journal of Physical Anthropology Annual $2001: 103$.

McCoy, P. C.

1979 Easter Island, in The Prehistory of Polynesia: 135-166, ed. J. D. Jennings. Cambridge: Harvard University Press. 
MCKinlay, J. R.

1974 Excavations at Sasoa'a: The historic phase, in Archaeology in Western Samoa, vol. 2: 13-35, ed. R. C. Green and J. M. Davidson. Bulletin of the Auckland Institute and Museum No. 7. Auckland: Auckland Institute and Museum.

MCNeILl, J. R.

1994 Of rats and men: Synoptic environmental history of the Island Pacific. Journal of World History $5: 299-349$.

NAGAOKA, L.

1993 Faunal assemblages from the To'aga Site, in The To 'aga Site: Three Millennia of Polynesian Occupation in the Manu'a Islands, American Samoa: 189-216, ed. P. V. Kirch and T. L. Hunt. Contributions of the University of California Archaeological Research Facility No. 51. Berkeley: University of California, Archaeological Research Facility.

Oliver, D. L.

1974 Ethnography. Vol. 1 of Ancient Tahitian Society. Honolulu: University of Hawai'i Press.

1989 Oceania: The Native Cultures of Australia and the Pacific, 2 vols. Honolulu: University of Hawai'i Press.

Pollock, N. J.

1992 These Roots Remain: Food Habits in Islands of the Central and Eastern Pacific since Western Contact. Honolulu: University of Hawai'i Press.

Ramis, D., AND P. Bover

2001 A review of the evidence for domestication of Myotragus balearicus Bate 1909 (Artiodactyla, Caprinae) in the Balearic Islands. Journal of Archaeological Science 28(3):265-282.

RAppaport, R. A.

1968 Pigs for the Ancestors: Ritual in the Ecology of a New Guinea People. New Haven: Yale University Press.

Rappaport, R. A., AND A. Rappaport

1967 Description of test excavations in coastal sites, in Archaeology on the Island of Mo 'orea, French Polynesia: 177-183, ed. R. C. Green, K. Green, R. Rappaport, A. Rappaport, and J. Davidson. Anthropological Papers of the American Museum of Natural History 51(2). New York: American Museum of Natural History.

Rolett, B. V.

1998 Hanamiai. Yale University Press Publications in Anthropology Number 81. New Haven: Department of Anthropology and the Peabody Museum, Yale University.

Rosendahl, P. H.

1994 Aboriginal Hawaiian structural remains and settlement pattern in the upland agricultural zone at Lapakahi, island of Hawai'i. Hawaiian Archaeology 3 :14-70.

Rosenzweig, M. L.

2004 Applying species-area relationships to the conservation of species diversity, in Frontiers of Biogeography: New Directions in the Geography of Nature: 325-343, ed. M. V. Lomolino and L. R. Heaney. Sunderland, MA: Sinauer Associates.

SCOTT, DEREK A.

1993 A Directory of Wetlands in Oceania. Slimbridge, UK: International Waterfowl and Wetlands Research Bureau.

SinOTO, Y. H.

1979 The Marquesas, in The Prehistory of Polynesia: 110-134, ed. J. D. Jennings. Cambridge: Harvard University Press.

Sinoto, Y. H., AND P. C. MCCoY

1974 Archaeology of Tetio'aroa Atoll, Society Islands. Interim Report No. 1. Honolulu: Department of Anthropology, Bernice P. Bishop Museum.

SPECHT, J.

1984 The Prehistoric Archaeology of Norfolk Island. Pacific Anthropological Records 34. Honolulu: Department of Anthropology, Bernice P. Bishop Museum.

Steadman, D. W.

1995 Prehistoric extinctions of Pacific Island birds: Biodiversity meets zooarchaeology. Science 267: 1123-1131. 
Suggs, R. C.

1961 The Archeology of Nuku Hiva, Marquesas Islands, French Polynesia. Anthropological Papers of the American Museum of Natural History 49(1). New York: American Museum of Natural History.

SutTon, D.

1982 The Chatham Islands, in The First Thousand Years: Regional Perspectives in New Zealand Archaeology: 160-178, ed. N. Prickett. New Zealand Archaeological Association Monograph 13. Palmerston North, New Zealand: Dunmore Press.

Thompson, L.

1971 The relations of men, animals, and plants in an island community (Fiji), in Polynesia: Readings on a Culture Area: 11-26, ed. A. Howard. Scranton, NY: Chandler Publishing Company.

Tітсомв, $M$.

1969 Dog and Man in the Ancient Pacific. Bernice P. Bishop Museum Special Publication 59. Honolulu: Star-Bulletin Printing Co.

Tuggle, D.

1997 The 'Ewa Plain. Hawaiian Archaeology 6:8-36.

VALERI, V.

1985 Kingship and Sacrifice: Ritual and Society in Ancient Hawaii. Trans. P. Wissing. Chicago: University of Chicago Press.

WALTER, R.

1998 Anai 'o: The Archaeology of a Fourteenth Century Polynesian Community in the Cook Islands. New Zealand Archaeological Association Monograph 22. Auckland: New Zealand Archaeological Association.

Walter, R., AND A. ANDERSON

2002 The Archaeology of Niue Island, West Polynesia. Honolulu: Bishop Museum Press.

WeISLER, M. I.

1994 The settlement of marginal Polynesia: New evidence from Henderson Island. Journal of Field Archaeology 21:83-102.

1995 Henderson Island prehistory: Colonisation and extinction on a remote Polynesian island. Biological Journal of the Linnean Society 56:377-404.

1996 Taking the mystery out of the Polynesian "mystery" islands: A case study from Mangareva and the Pitcairn Group, in Oceanic Culture History: Essays in Honour of Roger Green: 615-629, ed. J. Davidson, G. Irwin, F. Leach, A. Pawley, and D. Brown. New Zealand Journal of Archaeology Special Publication. Dunedin, New Zealand: Journal of Archaeology.

1997 Prehistoric long-distance interaction at the margins of Oceania, in Prehistoric Long-Distance Interaction in Oceania: An Interdisciplinary Approach: 149-172, ed. M. I. Weisler. New Zealand Archaeological Association Monograph 21. Auckland: New Zealand Archaeological Association.

WiLliams, J.

1837 A Narrative of Missionary Enterprises in the South Seas. New York: Appleton \& Co.

WOODHEAD, J. D., AND M. I. WeISLER

1997 Accurate sourcing of basaltic artefacts by radiogenic isotope analysis, in Prehistoric LongDistance Interaction in Oceania: An Interdisciplinary Approach: 212-223, ed. M. I. Weisler. New Zealand Archaeological Association Monograph 21. Auckland: New Zealand Archaeological Association.

Yen, D. E.

1973 The origins of Oceanic agriculture. Archaeology and Physical Anthropology in Oceania 8:6885.

YEN, D. E., AND J. GORDON, EDS.

1973 Anuta: A Polynesian Outlier in the Solomon Islands. Pacific Anthropological Records 21. Honolulu: Department of Anthropology, Bernice P. Bishop Museum.

ZIEGLER, A. C.

2002 Hawaiian Natural History, Ecology, and Evolution. Honolulu: University of Hawai'i Press. 


\section{ABSTRACT}

The significance of the domestic pig, Sus scrofa, to prehistoric Polynesians is hinted at by its inclusion among the species that they transported with them as they colonized Oceania. However, archaeological data reveal a pattern of pig distribution far more extensive in prehistory than at historic contact. Domestic mammal extirpation is a phenomenon apparently unique to prehistoric Polynesia. Although well recognized, the local extinction of domestic pigs in Polynesia prior to European contact has yet to be satisfactorily explained. Earlier accounts attributed the patchy distribution of pigs across the Island South Pacific to intentional extermination by their Polynesian keepers. More recent approaches seek to understand the disappearance of these animals within a biogeographic and ecological framework. Here, I test the hypothesis that the success of pig husbandry is correlated with ecological variables and demonstrate that the likelihood of pig extinction increases with decreasing island size. Keywords: Polynesia, domestic animals, pigs, island biogeography, extinction. 